Asian J. Med. Biol. Res. 2021, 7 (2), 138-146; doi: 10.3329/ajmbr.v7i2.54993

\author{
Asian Journal of \\ Medical and Biological Research \\ ISSN 2411-4472 (Print) 2412-5571 (Online) \\ www.ebupress.com/journal/ajmbr
}

\title{
Article \\ Proximate composition, amino acids, and fatty acids contents of dried shrimp products available in Jashore region, Bangladesh
}

\author{
Pranta Das ${ }^{1}$, Md. Salman ${ }^{1}$, Md. Aminur Islam ${ }^{2}$, Sharmin Suraiya ${ }^{3}$ and Monjurul Haq ${ }^{1 *}$ \\ ${ }^{1}$ Department of Fisheries and Marine Bioscience, Jashore University of Science and Technology, Jashore 7408, \\ Bangladesh \\ ${ }^{2}$ Department of Nutrition and Food Technology, Jashore University of Science and Technology, Jashore 7408, \\ Bangladesh \\ ${ }^{3}$ Department of Fisheries and Marine Bioscience, Bangabandhu Sheikh Mujibur Rahman Science and \\ Technology University, Gopalganj 8100, Bangladesh
}

*Corresponding author: Monjurul Haq, Ph.D., Associate Professor, Department of Fisheries and Marine Bioscience, Jashore University of Science and Technology, Jashore 7408, Bangladesh. Phone: +88 020421 2033; E-mail: mr.haq@just.edu.bd

Received: 01 May 2021/Accepted: 17 June 2021/ Published: 30 June 2021

\begin{abstract}
Dried shrimp has some special advantageous such as long shelf-life, high nutritional content, and ease of transportation considered as a healthy choice of food. The nutritional properties of three common and demandable dried shrimp species available in Jashore, Bangladesh were evaluated. The moisture content of dried Palaemon karnafuliensis, Metapenaeus Monoceros and Ferapenaeus indicus was determined 19.7 $\pm 0.40 \%$, $20.5 \pm 0.25 \%$ and $24.9 \pm 0.21 \%$, respectively. The protein content was found $57.46 \pm 5.88 \%, 62.5 \pm 1.98 \%$, and $55.5 \pm 1.85 \%$ in Palaemon karnafuliensis, Metapenaeus Monoceros, and Ferapenaeus indicus, respectively. The ash and fat content of Palaemon karnafuliensis, Metapenaeus Monoceros and Ferapenaeus indicus were observed $12.20 \pm 0.90 \%$ and $1.90 \pm 0.15 \%, 10.20 \pm 0.39 \%$ and $1.48 \pm 0.32 \%, 8.57 \pm 1.43 \%$, and $1.08 \pm 0.21 \%$, respectively. Total saturated fatty acids content was found $31.56 \%, 29.21 \%, 38.59$ in Palaemon karnafuliensis, Metapenaeus monoceros, and Ferapenaeus indicus, respectively. The polyunsaturated fatty acids was found 42.60\%, 42.29\%, and 37.80\% in Palaemon karnafuliensis, Metapenaeus monoceros, and Ferapenaeus indicus, respectively. There were nine non-essential and eight essential amino acids found in the dried shrimp products. Glutamine, proline, glycine and alanine were dominated among the non-essential amino acid. Lysine was found a significant amount in the study. All the three dried shrimp products were considered as highly nutritive and less fat value which is considered healthy for the consumers.
\end{abstract}

Keywords: amino acids; dried shrimps; fatty acids; proximate composition; $\omega-3$ polyunsaturated fatty acids

\section{Introduction}

Shrimps are one of the most commonly consumed aquatic organisms and are considered quite nutritious which provide high amounts of certain nutrients, such as iodine, that are not abundant in many other foods. The protein of shell fishes are considered as high quality due to containing essential amino acids required for the proper maintenance and normal growth of the human body. Shrimps are estimated to contain approximately $20 \%$ protein with well-balanced amino acids and other nutrients such as minerals and vitamins (Akonor et al., 2016). Shrimp lipids are rich in containing $\omega-3$ polyunsaturated fatty acids ( $\omega-3$ PUFAs) important for regulating normal human health and reducing the risk of cardiac problems, hypertension, tumors and cancers, inflammation, improve insulin sensitivity, optimize visual signaling and retain bone mass. The two abundant $\omega$ 3 PUFAs in seafoods, namely eicoapentanoic acid (EPA) and docosahexaenoic acid (DHA) perform vital role in 
the prevention of several health issues such as atherosclerosis, hypertension, stroke, depression, obesity, cancer, premature aging, etc. (Haq et al., 2018; Haq et al., 2017; Haq et al., 2017).

Shrimps contain high moisture and protein which make them susceptible to rapid deterioration. Spoilage of shrimps start shortly after capture unless those are preserved in cold are processed. However, maintaining cold chain and/or freeing of shrimp is a challenge where electricity is not very available and addition of value of the product (Akonor et al., 2016). In this circumstances, drying of small shrimp species are widely practiced in many countries during bulk capture. Drying has been used to preserve food all over the world since prehistoric times when people learned that sun-dried foods remain wholesome for a longer time. Drying of foods including shrimps reduces the moisture content to a safe level, which impacts some technological advantages, such as increased shelf-life, ease of handling and transportation, impartment of desirable characteristics such as odor, flavor, color, and taste (Ajifolokun et al., 2018). As water is essential for the activities of all living organisms, its removal slows down and stops microbial growth or autolytic activities. This is because microorganisms need water for growth and food enzymes cannot thrive without a watery environment, therefore drying can be effectively used as a method of preserving shrimps. Completely dried-shrimp or powdered shrimps have been widely accepted, as they can be used as spices in soups or foods for flavor and protein source (Akonor et al., 2016). Both fresh and dried are available in Bangladesh. For ensuring the long shelf life they are dried.

Among the various species of shrimps available in Bangladesh, Palaemon karnafuliensis, Metapenaeus monoceros, and Ferapenaeus indicus are three small and less commercial species used for sun-drying in coastal region. Some of the researcher investigated on the nutritional and chemical composition of commercial shrimp species, however, there is no report found available on the nutritional properties of small sun-dried shrimp species available in Bangladesh. It is assumed that the nutritional value of these small size shrimp is very high and considering these facts the present study was conducted to evaluate the proximate and nutritional composition. Therefore, the objectives of the study was to evaluate the proximate composition viz. protein, lipid, ash, and moisture content, the fatty acids, and amino acid composition of sun-dried shrimps available in Jashore region of Bangladesh.

\section{Materials and Methods}

\subsection{Reagents and instruments used}

Potassium sulfate, copper sulfate, sulfuric acid, sodium hydroxide, boric acid, $\mathrm{HCl}$, indicators (bromocresal green and methyle red) was purchased from Sigma-Aldrich Co., St. Louis, Missouri, USA. Hot air oven (Mod: PSO-451, MART, India), Muffle furnace (MF-205, Turkey), Soxhlet apparatus (Bher, Labor-Technik, Germany), Buchi Distillation unit (K-350), Kjeldhal digestion unit (Ra-158, Delhi), Rotary evaporator, Electric balance (Model: EK600i, Korea), and Amino acid analyzer (LA 8080, Hitachi, Japan) were used in this study. All the chemicals and reagents used in this study were of analytical grade.

\subsection{Collection and preparation of the sample}

Three species of dried shrimp samples were collected from Palbari market, Jashore. The species were selected based on the availability of dried shrimp at the region. Immediately after bought, the samples were packed in polyethelene bag to control air absorption from the atmosphere and brought to the laboratory. The samples were preserved at $-20^{\circ} \mathrm{C}$ to maintenance of nutritional quality unimpaired. The various dried samples were milled into fine powder using a blender, packaged, sealed and labeled for further analyses.

\subsection{Determination of moisture, protein, lipid, and ash content}

The proximate composition such as moisture, protein, lipid, and ash content of different dried shrimp products were determined by the methods of AOAC (2005).

\subsection{Determination of amino acid composition}

The amino acid composition and contents of different dried shrimp products was determined by the method described by Islam et al. (2020) with slight modifications. A high-speed amino acid analyzer (Model: LA 8080, Hitachi, Japan) equipped with a high-performance cation exchange column (Hitachi, Japan) was used for amino acid analysis maintaining column temperature at $57^{\circ} \mathrm{C}$. Briefly, $1 \mathrm{~g}$ sample was mixed with $25 \mathrm{~mL}$ of $6 \mathrm{~N} \mathrm{HCl}$ in a glass tube and heated at $110{ }^{\circ} \mathrm{C}$ for $24 \mathrm{~h}$, keeping in a sand bath. The heated sample was dried by evaporating $\mathrm{HCl}$ and $6 \mathrm{~mL}$ distilled water was added for diluting the homogenates. Then the solution was filtered by using a $0.45 \mu \mathrm{m}$ syringe filter. 


\subsection{Determination of fatty acid composition}

The fatty acid composition of different dried shrimp products oils (previously extracted by Soxhlet apparatus for lipid content estimation) was analyzed by using a 6890 model gas chromatograph (Agilent Technologies, Wilmington, USA). The instrument was equipped with a fused silica capillary column (length: 100m, internal diameter: $0.25 \mathrm{~mm}$, and $0.2 \mu \mathrm{m}$ film (Supelco, Bellefonte, USA). The fatty acids of triacylglycerol were converted to fatty acid methyl esters following the procedure of the American Oil Chemists Society (AOCS, 2006). The oven temperature was increased to $130{ }^{\circ} \mathrm{C}$ in $3 \mathrm{~min}$, later increased to $240{ }^{\circ} \mathrm{C}$ at a rate of $4{ }^{\circ} \mathrm{C} / \mathrm{min}$, and then soaked for $10 \mathrm{~min}$. The temperature of injector and detector were maintained at $250{ }^{\circ} \mathrm{C}$. The fatty acids methyl esters of Thai pangus fish muscle oil was identified comparing with the standards of fatty acids methyl esters (Supelco ${ }^{\mathrm{R}} 37$ Components of FAME Mix, Bellefonte, PA, USA) and quantification was done by obtained peak area $(\%)$.

\subsection{Statistical analyses}

Values are presented as means \pm standard deviations of triple determinations. The data were analyzed by oneway analysis of variance (ANOVA) using SPSS 20.0 (SPSS Inc., Chicago, IL). Difference between the means was determined by Duncan's Multiple Range Tests (DMRT) and $\mathrm{P}<0.05$ was regarded as significant.

\section{Results and Discussion}

\subsection{Moisture contents}

The proximate composition of different dried shrimp products are shown in Table 1. Proximate composition varied among the dried shrimp species. Application of heat used in drying method plays a significant role in the influence of chemical composition. In the present study, the moisture content of Palaemon karnafuliensis, Metapenaeus monoceros, and Ferapenaeus indicus were found $19.70 \pm 0.40 \%, 20.50 \pm 0.25 \%, 24.90 \pm 0.21 \%$, respectively. The highest moisture content was $24.90 \% \pm 0.21 \%$ in Ferapenaeus indicus. All these three species contained comparatively higher moisture content, which might be affected by drying temperature, duration, and storage time. This study showed little similarity to Akuamoa et al. (2018) who reported that the moisture content of the shrimp were significantly affected by the radiation treatment and source of shrimp. The study stated that the moisture contents normally $11.9 \%$ to $17.76 \%$ in the shrimp. On the other hand Ajifolokun et al. (2018) reported that the sun dried shrimp powder had the highest moisture content of $13.70 \%$ which is relatively lower than this study. Rosemary et al. (2020) found the moisture content of market dried shrimp $15.92 \% \pm$ $0.23 \%$ and home dried shrimp $9.5 \% \pm 00 \%$. Ehigiator and Akise (2013) reported the moisture content $9.10 \pm$ $0.33 \%$ in the flesh. So it can be said that the moisture content of present study is relatively higher comparing with other researchers.

Table 1. Proximate composition of dried shrimp products.

\begin{tabular}{lcccc}
\hline Sample & Ash (\%) & Moisture (\%) & Protein (\%) & Fat (\%) \\
\hline Palaemon karnafuliensis & $12.20^{\mathrm{a}} \pm 0.90$ & $19.70^{\mathrm{b}} \pm 0.40$ & $57.46^{\mathrm{b}} \pm 1.88$ & $1.90^{\mathrm{a}} \pm 0.15$ \\
Metapenaeus monoceros & $10.20^{\mathrm{b}} \pm 0.39$ & $20.50^{\mathrm{b}} \pm 0.25$ & $62.50^{\mathrm{a}} \pm 1.98$ & $1.48^{\mathrm{a}} \pm 0.32$ \\
Ferapenaeus indicus & $8.57^{\mathrm{c}} \pm 1.43$ & $24.90^{\mathrm{a}} \pm 0.21$ & $55.50^{\mathrm{c}} \pm 1.85$ & $1.08^{\mathrm{b}} \pm 0.21$
\end{tabular}

Note: Values are presented as means \pm standard deviation of triplicates. Different superscript small letters on each column indicate significant $(P \leq 0.05)$ differences.

\subsection{Protein contents}

In the study, the protein contents of Palaemon karnafuliensis, Metapenaeus monoceros, and Ferapenaeus indicus were found $57.46 \pm 5.88 \%, 62.50 \pm 1.98 \%, 55.50 \% \pm 1.85 \%$, respectively. Metapenaeus monoceros contained more amount of protein than others but no significant variation was found. Rosemary et al. (2020) showed the protein content of market smoke dried shrimp 51.07 $\pm 0.00 \%$ and home smoke dried shrimp $67.34 \pm$ $0.00 \%$. The temperature played a significant role because higher temperature causes protein denaturation. 
Ajifolokun et al. (2018) found the protein content $58.4 \pm 0.51 \%$ in the sun dried shrimp. They observed that the lower the drying temperature, the higher the protein content. This supported the findings of Begum et al. (2013 (2013) that the increase in drying temperature and moisture loss results in denaturation of protein. Ehigiator and Akise (2013) reported that the protein content of the flesh of Macrobrachium vollenhovenii $41.94 \pm 0.69 \%$. As the study worked with fresh shrimp and it contained lots of moisture, the protein contents relatively were lower than the dried shrimp. Akonor et al. (2016) found the protein content of solar dried shrimp 86.21 $\pm 0.08 \%$. Ravichandran et al. (2009) also reported the protein content of flesh of white shrimp to be $41.30 \%$ whereas the shell contained $32.5 \%$. Zarehgashti et al. (2019) stated the protein content in dried shrimp meat was 72.74 $\pm 1.99 \%$ of dry weight. So the protein content of dried shrimp products in the present study could be compared with the previous reports.

\subsection{Ash contents}

In the present study, the ash content of Palaemon karnafuliensis, Metapenaeus monoceros, and Ferapenaeus indicus were found $14.20 \pm 0.90 \%, 11.20 \pm 0.39 \%$, and $12.57 \pm 1.43 \%$, respectively. The highest ash content $14.20 \pm 0.90 \%$ was found in Palaemon karnafuliensis and the lowest ash content $11.20 \pm 0.39 \%$ was found in Metapenaeus monoceros. In this study, it is observed that the higher moisture content resulted in lower ash content. This result is quite similar with Ajifolokun et al. (2018) who found the ash content of sun dried shrimp $6.77 \pm 0.05 \%$. They agreed the higher ash content was due to the significant moisture loss because ash content is affected by moisture content and temperature. Akuamoa et al. (2018) found the ash content $13.80 \pm 0.09 \%$ to $15.42 \pm 0.09 \%$ in dry smoked Penaeus notialis. Zarehgashti et al. (2019) found the ash content $9.33 \pm 0.00 \%$ in dried shrimp meat. Rosemary et al. (2020) reported the ash content $10.34 \pm 0.72 \%$ in market dried shrimp and $8.95 \pm 0.07 \%$ in the home dried shrimp. Islam et al. (2017) reported the ash content $0.87 \pm 0.06 \%$ in cultured fresh shrimp and $0.75 \pm 0.11 \%$, in wild fresh shrimp. So it can be said that this present study is quite similar with other previous reports.

\subsection{Lipid contents}

The lipid contents of these three dried shrimp products were found very much similar. Fat contents of Palaemon karnafuliensis, Metapenaeus monoceros, and Ferapenaeus indicus were found $1.90 \pm 0.15 \%, 1.48 \pm 0.32 \%$, and $1.08 \pm 21 \%$, respectively. In the present study, the dried shrimp products contained very small amount of lipid. Akonor et al. (2016) reported the fat content $5.74 \pm 0.11 \%$ in the solar dried shrimp meat which was relatively higher than this present study. Sriket et al. (2007) have reported in previous study that the fat content of some shrimp species ranged between 1.2 and $1.3 \%$ of whole body weight (wb). Wu and Mao (2008) notified shrimp meat contained about $2 \%$ fat (wb), but this reduced significantly to less than $2 \%$ after drying. This reduction might be due to drying; fat may have exuded along with moisture evaporation or oxidized into other compounds since shrimp lipids are mainly made up of polyunsaturated fatty acids. Ajifolokun et al. (2018) found the fat content $1.98 \pm 0.01 \%$ in the sun dried shrimp which is very similar with this present study. They reported that the fat content of shrimp depended on moisture content which were in inverse relationship; agreed with this present study. This supported the results of Chukwu and Shaba (2009) that the lower the fat content, the higher the moisture content of shrimp. Bhavani and Karuppasamy (2014) also reported about $2.5 \%$ fat content in all shrimps evaluated. So all those previous research is almost similar with this present study.

\subsection{Amino acid composition}

The chromatograms of amino acids detected by amino acid analyzer in dried shrimp products are presented in Figure 1. All the non-essential amino acid obtained in the dried shrimp in this study is shown in Table 2. In the study, nine non-essential amino acids were found of which aspartic, glutamine, glycine, alanine and proline were dominated. All these three shrimp species contained almost similar amount of non-essential amino acid. Metapenaeus monoceros contained the highest amount of non-essential amino acids (10.52\%) followed by Palaemon karnafuliensis (8.68\%) and Ferapenaeus indicus (7.20\%). The lowest amount of non-essential amino acid was cysteine found in this study. Proline was dominated among this non-essential amino acid. Cysteine was considered as the minimal portion in these shrimp species. Mente et al. (2002) found eleven non-essential amino 
acids in small juvenile shrimp ( $2 \mathrm{~g}$ ). In that previous study, it was notified that the Glycine, Alanine, and Proline were mostly abundant in juvenile shrimp.

Table 2. Non-essential amino acids composition $(\mathrm{g} / 100 \mathrm{~g})$ in dried shrimp products.

\begin{tabular}{llll}
\hline Non-essential amino acid & Palaemon karnafuliensis & Metapenaeus monoceros & Ferapenaeus indicus \\
\hline Asp & $1.04 \pm 0.01^{\mathrm{c}}$ & $1.50 \pm 0.03^{\mathrm{a}}$ & $1.16 \pm 0.02^{\mathrm{b}}$ \\
Ser & $0.56 \pm 0.02^{\mathrm{b}}$ & $0.64 \pm 0.01^{\mathrm{a}}$ & $0.50 \pm 0.01^{\mathrm{c}}$ \\
Glu & $1.99 \pm 0.08^{\mathrm{a}}$ & $2.08 \pm 0.04^{\mathrm{a}}$ & $1.66 \pm 0.02^{\mathrm{b}}$ \\
Gly & $1.35 \pm 0.01^{\mathrm{b}}$ & $1.53 \pm 0.01^{\mathrm{a}}$ & $0.86 \pm 0.007^{\mathrm{c}}$ \\
Ala & $1.06 \pm 0.02^{\mathrm{b}}$ & $1.23 \pm 0.02^{\mathrm{a}}$ & $0.83 \pm 0.02^{\mathrm{c}}$ \\
Cys & $0.05 \pm 0.005^{\mathrm{a}}$ & $0.06 \pm 0.005^{\mathrm{a}}$ & $0.05 \pm 0.005^{\mathrm{a}}$ \\
Ile & $0.47 \pm 0.17^{\mathrm{b}}$ & $0.52 \pm 0.015^{\mathrm{a}}$ & $0.47 \pm 0.03^{\mathrm{b}}$ \\
Tyr & $0.42 \pm 0.005^{\mathrm{b}}$ & $0.84 \pm 0.05^{\mathrm{a}}$ & $0.22 \pm 0.03^{\mathrm{c}}$ \\
Pro & $1.71 \pm 0.02^{\mathrm{b}}$ & $2.08 \pm 0.12^{\mathrm{a}}$ & $1.43 \pm 0.08^{\mathrm{c}}$ \\
\hline$\sum$ Non-essential amino acid & $\mathbf{8 . 6 8}$ & $\mathbf{1 0 . 5 2}$ & $\mathbf{7 . 2 0}$
\end{tabular}

Note: Values are presented as means \pm standard deviation of triplicates. Different superscript small letters on each row indicate significant $(P \leq 0.05)$ differences.

Table 3. Essential amino acids composition $(\mathrm{g} / 100 \mathrm{~g})$ in dried shrimp products.

\begin{tabular}{llll}
\hline Essential amino acid & Palaemon karnafuliensis & Metapenaeus monoceros & Ferapenaeus indicus \\
\hline Thr & $0.51 \pm 0.03^{\mathrm{b}}$ & $0.62 \pm 0.005^{\mathrm{a}}$ & $0.45 \pm 0.005^{\mathrm{c}}$ \\
Val & $0.67 \pm 0.02^{\mathrm{b}}$ & $0.78 \pm 0.005^{\mathrm{a}}$ & $0.67 \pm 0.02^{\mathrm{b}}$ \\
Met & $0.29 \pm 0.005^{\mathrm{b}}$ & $0.32 \pm 0.01^{\mathrm{a}}$ & $0.28 \pm 0.01^{\mathrm{c}}$ \\
$\mathrm{Arg}$ & $0.66 \pm 0.02^{\mathrm{b}}$ & $0.73 \pm 0.01^{\mathrm{a}}$ & $0.38 \pm 0.02^{\mathrm{c}}$ \\
Leu & 0.00 & 0.00 & $0.63 \pm 0.04^{\mathrm{a}}$ \\
Phe & $1.12 \pm 0.06^{\mathrm{a}}$ & $0.47 \pm 0.02^{\mathrm{b}}$ & $0.39 \pm 0.04^{\mathrm{b}}$ \\
His & $0.17 \pm 0.005^{\mathrm{b}}$ & $0.19 \pm 0.005^{\mathrm{a}}$ & $0.16 \pm 0.01^{\mathrm{b}}$ \\
Lys & $1.47 \pm 0.11^{\mathrm{a}}$ & $1.22 \pm 0.01^{\mathrm{b}}$ & $1.01 \pm 0.04^{\mathrm{c}}$ \\
\hline$\sum$ Essential amino acid & $\mathbf{4 . 9 1}$ & $\mathbf{4 . 3 6}$ & $\mathbf{3 . 9 8}$ \\
\hline
\end{tabular}

Note: Values are presented as means \pm standard deviation of triplicates. Different superscript small letters on each row indicate significant $(P \leq 0.05)$ differences.

All the essential amino acids content in this study is shown in Table 3. There were eight essential amino acids found in this study. Among them Lysine was mostly derived. Palaemon karnafuliensis contained the highest amount of essential amino acid with $4.90 \%$. Leucine was not found in Palaemon karnafuliensis and Metapenaeus monoceros but Ferapenaeus indicus contained a small amount (0.63\%). Mente et al. (2002) found ten essential amino acids in the juvenile of $M$. rosenbergii. In that study lysine was dominated among these essential amino acid. Bhavan et al. (2010) detected eighteen amino acids where eleven were essential and seven were non-essential in the muscle of prawn. According to that study phenylalanine, leucine, valine and arginine were found to be statistically significant. Lysine is an amino acid highly significant for a healthy diet and nutrition. Cobb et al. (1975) observed the stacean muscles contained high content of free amino acids, such as arginine, glycine, proline, glutamine and alanine. The amino acid, tryptophan plays an important role in the brain as a precursor of the neurotransmitter, serotonin, which has a major effect on the feeding behavior of animals. Wilson et al. (2002) observed valine is involved in many metabolic pathways and is considered indispensable for protein synthesis and optimal growth. Abe and Ohmama (1987) reported that histidine is also 
an indispensable amino acid involved in many metabolic functions including the production of histamines, which take part in allergic and inflammatory reactions.
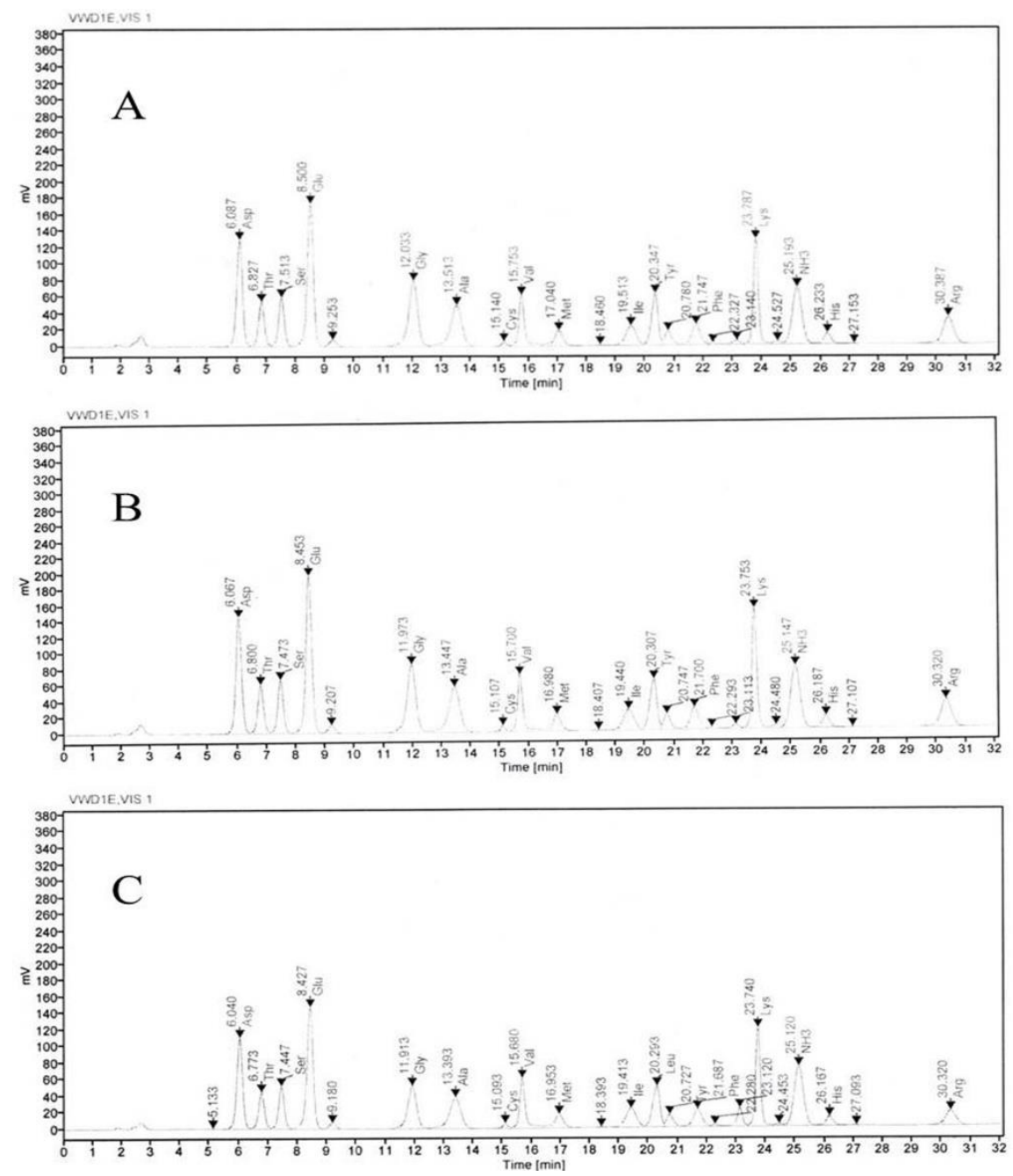

Figure 1. Amino acid chromatogram of dried shrimp products (A) Palaemon karnafuliensis; (B) Metapenaeus monoceros; (C) Ferapenaeus indicus.

\subsection{Fatty acid composition of dried shrimp products}

The saturated, polyunsaturated, and monounsaturated fatty acid composition of different dried shrimp products are shown in Table 4. Omega-3 fatty acid composition of different dried shrimp products are shown in Figure 2. Total twelve fatty acids were identified. The quantity of lipid is not found significantly difference but the fatty acid composition was found different among various dried shrimp products. The most abundant fatty acid was palmitic acid in this study followed by oleic acid, linoleic acid and cis-4, 7, 10, 13, 16, 19-docosahexanoic acid. Most saturated fatty acids content find in Ferapenaeus indicus (38.6\%) in this study. The saturated fatty acids content of Metapenaeus monoceros and Palaemon karnafuliensis was found $29.21 \%$ and $31.56 \%$, respectively. Polyunsaturated fatty acids dominated in this study compared to saturated and monounsaturated fatty acid.

The amount of polyunsaturated fatty acids in Palaemon karnafuliensis and Metapenaeus monoceros were observed $42.6 \%$ and $42.29 \%$, respectively. Ferapenaeus indicus contained $37.80 \%$ of polyunsaturated fatty acid. The amount of linoleic acid dominates this polyunsaturated fatty acids composition. Only one monounsaturated fatty acid (Oleic acid) is found in this study. Luzia et al. (2003) reported the PUFA content was decreased during drying in fish species. Sriket et al. (2007) observed the PUFA was mostly esterified to phospholipids rather than triacylglycerol. Henna et al. (2011) reported the marine phospholipid was more resistant to oxidation than bulk fish oil (mostly triacylglycerol) from the same sources. According to that explanation there were observed an insignificant changes in the content of EPA and DHA during the drying process of shrimps. 
Table 4. Fatty acids composition (area \%) of different dried shrimp products.

\begin{tabular}{|c|c|c|c|}
\hline Name of fatty acids & Palaemon karnafuliensis & Metapenaeus monoceros & Ferapenaeus indicus \\
\hline Palmitic Acid (C16:0) & $24.87 \pm 0.07^{\mathrm{b}}$ & $20.29 \pm 0.05^{\mathrm{c}}$ & $28.59 \pm 0.03^{\mathrm{a}}$ \\
\hline Stearic Acid (C18:0) & $4.30 \pm 0.05^{\mathrm{c}}$ & $5.46 \pm 0.02^{b}$ & $6.00 \pm 0.05^{\mathrm{a}}$ \\
\hline Arachidic Acid (C20:0) & $0.11 \pm 0.03^{\mathrm{c}}$ & $0.32 \pm 0.04^{\mathrm{b}}$ & $0.51 \pm 0.06^{\mathrm{a}}$ \\
\hline Behenic Acid (C22:0) & $0.07 \pm 0.01^{\mathrm{a}}$ & $0.05 \pm 0.02^{\mathrm{a}}$ & $0.10 \pm 0.02^{\mathrm{a}}$ \\
\hline Lignoceric Acid (C24:0) & $0.04 \pm 0.03^{\mathrm{b}}$ & $0.10 \pm 0.04^{\mathrm{a}, \mathrm{b}}$ & $0.13 \pm 0.03^{\mathrm{a}}$ \\
\hline$\sum$ Saturated fatty acids & 31.56 & 29.21 & 38.59 \\
\hline Oleic Acid (C18:1n9C) & $25.70 \pm 0.05^{\mathrm{a}}$ & $27.41 \pm 0.04^{\mathrm{b}}$ & $23.52 \pm 0.01^{\mathrm{c}}$ \\
\hline$\sum$ Monounsaturated fatty acids & 25.70 & 27.41 & 23.52 \\
\hline Linoleic Acid (C18:2n6c) & $18.08 \pm .03^{\mathrm{b}}$ & $18.44 \pm 0.08^{\mathrm{a}}$ & $14.20 \pm 0.02^{\mathrm{c}}$ \\
\hline Linolenic Acid (C18:3n3) & $2.82 \pm .05^{\mathrm{b}}$ & $3.07 \pm 0.05^{\mathrm{a}}$ & $1.30 \pm 0.03^{\mathrm{c}}$ \\
\hline $\begin{array}{l}\text { Arachidic Acid (C20:4) } \\
\text { cis-5,8,11,14,17 }\end{array}$ & $3.13 \pm 0.04^{\mathrm{a}}$ & $2.31 \pm 0.04^{b}$ & $3.02 \pm 0.02^{\mathrm{b}}$ \\
\hline $\begin{array}{l}\text { Eicosapentanoic Acid (C20:5n3) } \\
\text { Cis-4, } 7,10,13,16,19\end{array}$ & $6.54 \pm 0.05^{\mathrm{c}}$ & $8.46 \pm 0.05^{\mathrm{a}}$ & $7.01 \pm 0.06^{\mathrm{b}}$ \\
\hline Docosahexanoic Acid (C22:6n3) & $12.01 \pm .05^{\mathrm{a}}$ & $9.99 \pm .09^{\mathrm{b}}$ & $12.26 \pm 0.07^{\mathrm{a}}$ \\
\hline$\sum$ Polyunsaturated fatty acids & 42.60 & 42.29 & 37.80 \\
\hline
\end{tabular}

Values are presented as means ( \pm ) standard deviation of triplicates. Different small letters on each row indicate significant $(p \leq .05)$ differences.

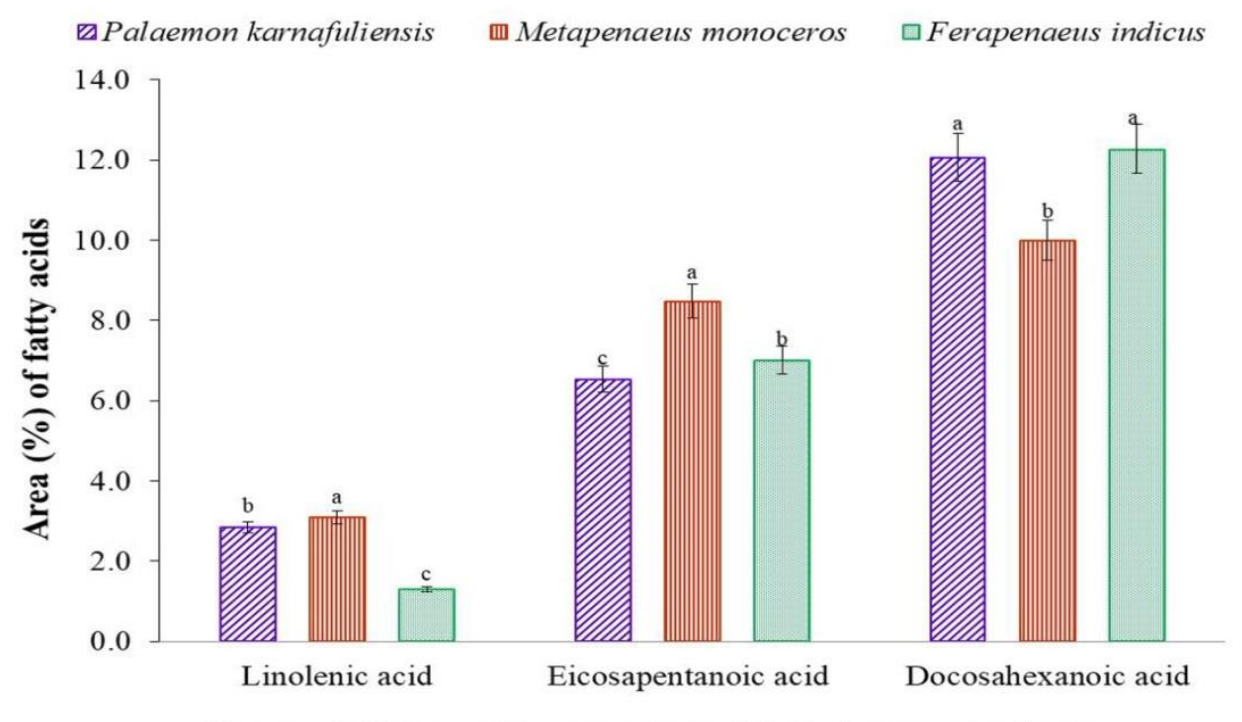

Omega-3 fatty acids contents in dried shrimp products

Figure 2. Omega-3 fatty acid composition of different dried shrimp products.

Palmitic (C16:0) and stearic (C18:0) acids were reported to be the most abundant saturated fatty acids $P$. vulgaris, P. brasiliensis, P. schimitti, P. vannamei, P. monodon, and X. kroyeri (Bragagnolo and RodriguezAmaya, 2001; Luzia et al., 2003; Sriket et al., 2007). Saglik and Imre (1997) determined 23.1\% Palmitic acid (C16:0) and 6.2\% stearic acid (C18:0) in P. longirostris; meanwhile they determined $19.1 \%$ Palmitic acid (C16:0) and $11.2 \%$ stearic acid (C18:0) in P. semisulcatus. These values were almost similar to the results of this study. In this present study, oleic acid (C18:1n9C) was dominated monounsaturated fatty acid in the studied dried shrimp products. Metapenaeus monoceros contained the highest amount of oleic acid (C18:1n9C) which was $27.41 \%$. Yerlikaya et al. (2013) found the oleic acid (C18:1n9) and palmitoleic acid (C16:1) were dominant monounsaturated fatty acids in shrimps. Heu et al. (2003) observed the Northern pink shrimp and spotted shrimp contained the highest amount of oleic acid (C18:1n9C) followed by palmitoleic acid (C16:1) and cisvaccenic acid (C18:1n7). Sampaio et al. (2006) compared fatty acid profile of the dried shrimp species in various seasons (summer, autumn, and winter). They reported that shrimps contained a total of saturated fatty acids of $27.49 \%$, monounsaturated fatty acids of $43.73 \%$, polyunsaturated fatty acids of $28.79 \%$ and EPA and DHA of $19.96 \%$. Therefore, results of this present study and other previous studies indicated that dried shrimp meats included sufficient contents of beneficial fatty acids which are necessary to prevent many diseases. 


\section{Conclusions}

The present report describes the major nutritional values of three different dried shrimp products. Though there was slight variation in bio-chemical composition in these three species, all of the species were highly nutritive. In this study, it was observed that the dried shrimp contained significant amount of protein compared to fresh one. Due to low moisture content, the dried shrimp species deserve long shelf life and prevent microbial effect. There are significant contents of essential amino acid found in this study which are very much needed for our health. The dried shrimp products contained substantial amount of $\omega-3$ polyunsaturated fatty acids which make it popular among health cautious people. The study also found that the fat contents in these shrimp species were low which makes it more dietary and easily digestible.

\section{Conflict of interest}

None to declare.

\section{References}

Abe H and S Ohmama, 1987. Effect of starvation, and seawater acclimation on the concentration and free Lhistidine and related dipeptides in the muscle of eel, rainbow trout and Japanese dace. Comp. Biochem. Physiol., 88: 507-511.

Ajifolokun OM, AK Basson, FO Osunsanmi and GE Zharare, 2018. Effects of drying methods on quality attributes of shrimps. J. Food Process. Tech., 10: 2.

Akonor PT, H Ofori, NT Dziedzoave and NK Kortei, 2016. Drying characteristics and physical and nutritional properties of shrimp meat as affected by different traditional drying techniques. Int. J. Food Sci., 2016:1-5.

Akuamoa F, GT Odamtten and NK Kortei, 2018. Nutritional and shelf-life studies of dry smoked and gamma irradiated shrimps (Penaeus notialis) from three different water sources in Ghana. Cogent Food Agricult., 4: 1505803.

AOAC. Official Methods of Analysis. 18th edn. Association of Official Analytical Chemists; Arlington, VA, USA: 2005.

AOCS. 2006. Official Method. .American Oil Chemists' Society, Champaign, Illinois, USA.

Begum M, M Begum, SU Ahmed and T Akter. 2013. Studies on the effectiveness of Tejpata (Cinnamomum tamala Nee) leaf extract on dried kachki (Corica soborna) fish preservation in laboratory condition. Am. J. Food Technol., 1: 14-17.

Bhavan PS, S Radhakrishnan, C Seenivasan, R Shanthi, R Poongodi and S Kannan, 2010. Proximate composition and profiles of amino acids and fatty acids in the muscle of adult males and females of commercially viable prawn species Macrobrachium rosenbergii collected from natural culture environments. Int. J. Biol., 2: 107.

Bhavani K and R Karuppasamy, 2014. Acute toxicity bioassay and behavioural changes on Zebra fish, Danio rerio (Hamilton) under arsenic trioxide. Int. J. Mod. Res. Rev., 2: 40-46.

Bragagnolo N and DB Rodriguez-Amaya, 2001. Total lipid, cholesterol, and fatty acids of farmed freshwater prawn (Macrobrachium rosenbergii) and wild marine shrimp (Penaeus brasiliensis, Penaeus schimitti, Xiphopenaeus kroyeri). J. Food Comp. Anal., 14: 359-369.

Chukwu O and Shaba IM, 2009. Effects of drying methods on proximate compositions of catfish (Clarias gariepinus). World. J. Agr. Sci. 5: 114-116.

Cobb BF, FS Conte and MA Edwards, 1975. Free amino acids and osmoregulation in penaeid shrimp, J. Agric. Food Chem., 23: 1172-1174.

Ehigiator FAR and OG Akise, 2013. Proximate composition, macro and trace mineral compositions of different body parts of Macrobrachium vollenhovenii from Ovia River in Edo State, Nigeria. Trop. Freshwat. Biol,. 22: 1 .

Haq M, AT Getachew, PS Saravana, YJ Cho, SK Park, MJ Kim and BS Chun, 2017. Effects of process parameters on EPA and DHA concentrate production from Atlantic salmon by-product oil: Optimization and characterization. Korean J. Chem. Eng., 34: 2255-2264.

Haq M, R Ahmed, YJ Cho and BS Chun, 2017. Quality properties and bio-potentiality of edible oils from Atlantic salmon by-products extracted by supercritial carbon dioxide and conventional methods. Waste Biomass Valori. 8: 1953-1967.

Haq M, SK Park, MJ Kim, YJ Cho and BS Chun, 2018. Modifications of Atlantic salmon by-product oil for obtaining different $\omega-3$ polyunsaturated fatty acids concentrates: An approach to comparative analysis. J. Food Drug Anal., 26: 545-556. 
Henna-Lu FS, NS Nielsen, M Timm-Heinrich, C Jacobsen, 2011. Oxidative stability of marine phospholipids in the liposomal form and their applications. Lipids, 46: 3-23.

Heu MS, JS Kim and F Shahidi, 2003. Components and nutritional quality of shrimp processing byproducts. Food Chem., 82: 235-242.

Islam A, S Mondal, S Bhowmik, S Islam and M Begum, 2017. A comparative analysis of the proximate composition of wild and cultured prawn (Macrobrachium rosenbergii) and shrimp (Penaeus monodon). Int. J. Fish. Aquat. Sci., 5: 59-62.

Islam MA, M Mohibbullah, S Suraiya, M Sarower-E-Mahfuj, S Ahmed and M Haq, 2020. Nutritional characterization of freshwater mud eel (Monopterus cuchia) muscle cooked by different thermal processes. Food Sci. Nutr. 8: 6247-6258.

Luzia LA, GR Sampaio, CM Castellucci and EA Torres, 2003. The influence of season on the lipid profiles of five commercially important species of Brazilian fish. Food Chem. 83: 93-97.

Mente E, P Coutteau, D Houlihan, I Davidson and P Sorgeloos, 2002. Protein turnover, amino acid profile and amino acid flux in juvenile shrimp Litopenaeus vannamei: effects of dietary protein source. J. Expt. Biol. 205: 3107-3122.

Ravichandran S, G Rameshkumar and A Rosario, 2009. Biochemical composition of shell and flesh of the Indian white shrimp Penaeus indicus (H. milne Edwards 1837). American-Eurasian J. Sci. Res., 4: 191-194.

Rosemary NO, O Omokaro, SA Wemedo and DN Ogbonna, 2020. Microbiological and nutritional quality of market and home smoke dried shrimp. J. Adv. Microbiol., 20: 35-42.

Sağlı S and S Imre, 1997. Fatty acid composition and cholesterol content of mussel and shrimp consumed in Turkey. Turk. J. Mar. Sci., 3: 179-189.

Sampaio GR, DHM Bastos, RAM Soares, YS Queiroz, EAFS Torres, 2006. Fatty acids and cholesterol oxidation in salted and dried shrimp. J. Food Chem., 95: 344-351.

Sriket P, S Benjakul, W Visessanguan and K Kijroongrojana, 2007. Comparative studies on chemical composition and thermal properties of black tiger shrimp (Penaeus monodon) and white shrimp (Penaeus vannamei) meats. Food Chem., 103: 11991207.

Wilson RP, 2002. Amino acids and protein. In J.E. Halver \& R.W. Hardy (Eds.), Fish Nutrition, (pp. 143-179). Academic Press, San Diego. CA, USA.

$\mathrm{Wu} \mathrm{T}$ and $\mathrm{L} \mathrm{Mao,} \mathrm{2008.} \mathrm{Influences} \mathrm{of} \mathrm{hot} \mathrm{air} \mathrm{drying} \mathrm{and} \mathrm{microwave} \mathrm{drying} \mathrm{on} \mathrm{nutritional} \mathrm{and} \mathrm{odorous}$ properties of grass carp (Ctenopharyngodon idellus) fillets. Food Chem., 110: 647-653.

Yerlikaya P, OK Topuz, HA Buyukbenli and N Gokoglu, 2013. Fatty acid profiles of different shrimp species: Effects of depth of catching. J. Aquat. Food Prod. Technol., 22: 290-297.

Zarehgashti G, Y Etemadian, AR Valipour, M Rahnama, F Khodabandeh and A Fahim, 2019. Production of a semi ready-to-eat shrimp soup powder and assessment of its shelf life. Nutr.Food Sci. Res. 6: 41-50. 